\title{
Clozapine-resistant schizophrenia - non pharmacological augmentation methods
}

\author{
Schizofrenia lekooporna - niefarmakologiczne metody augmentacji leczenia klozapiną
}

\author{
Joanna Gałaszkiewicz ${ }^{1} \mathrm{ABEF}$, Krzysztof Rębisz ${ }^{1} \mathrm{AB}$, \\ Justyna Morylowska-Topolska ${ }^{2}$ ABE, Hanna Karakuła-Juchnowicz ${ }^{1}$ ABE, \\ Gustaw Kozak ${ }^{1} \mathrm{AB}$
}

1I Department of Psychiatry, Psychotherapy and Early Intervention, Medical University of Lublin 2 Department of Clinical Neuropsychiatry, Medical University of Lublin

\section{Abstract}

Clozapine is the drug of choice for drug-resistant schizophrenia, but despite its use, $30-40 \%$ patients fail to achieve satisfactory therapeutic effects. In such situations, augmentation attempts are made by both pharmacological and non-pharmacological methods. To date, most of the work has been devoted to pharmacological strategies, much less to augemantation of clozapine with electroc onvulsive therapy (C+ECT), transcranial direct current stimulation (tDCS) or transcranial magnetic stimulation (TMS).

Aim: The aim of the work is to present biological, non-pharmacological augmentation treatment methods with clozapine.

Material and methods: A review of the literature on non-pharmacological augmentation treatment methods with clozapine was made. PubMed database was searched using key words: drug-resistant schizophrenia, clozapine, ECT, transcranial magnetic stimulation, transcranial electrical stimulation and time descriptors: 1980-2017.

Results: Most studies on the possibility of increasing the efficacy of clozapine was devoted to combination therapy with clozapine + electric treatments. They have shown improved efficacy when using these two methods simultaneously from 37.5 to $100 \%$. The only randomized trial so far has also confirmed the effectiveness of this procedure. Despite the described side effects of tachycardia or prolonged seizures, most studies indicate the safety and efficacy of combined use of clozapine and electroconvulsive therapy.Transcranial magnetic stimulation also appears to be a safe method in patients treated with clozapine. However, further research is needed before ECT can be included in standard TRS treatment algorithms. The data for combining transcranial electrical stimulation with clozapine, come only from descriptions of cases and need to be confirmed in controlled studies.

Conclusions: The results of studies on the possibility of increasing the effectiveness of clozapine using biological non-pharmacological treatment methods indicate a potentially beneficial effect of this type of methods in breaking the super-resistance in schizophrenia. Combination of clozapine and ECT can be considered as the most recommended strategy among these treatment methods.

Keywords: drug-resistant schizophrenia, clozapine, ECT, TMS, tDCS

\section{Streszczenie}

Klozapina pozostaje lekiem z wyboru w przypadku schizofrenii lekoopornej, jednak pomimo jej zastosowania, u 30-40\% pacjentów nie udaje się uzyskać satysfakcjonujących efektów terapeutycznych. W takich sytuacjach podejmowane są próby augmentacji zarówno metodami farmakologicznymi jak i niefarmakologicznymi. Do chwili obecnej najwięcej prac poświęcono strategiom farmakologicznym, znacznie mniej kojarzeniu klozapiny z elektrowstrząsami (EW), przezczaszkową stymulacją elektryczną (tDCS) lub magnetyczną (TMS).

Cel: Celem pracy jest prezentacja biologicznych, niefarmakologicznych sposobów augmentacji leczenia klozapiną.

Materiał i metoda: Dokonano przeglądu literatury dotyczącej sposobów niefarmakologicznej augmentacji leczenia klozapiną. Korzystano z bazy PubMed, używając słów-kluczy: schizofrenia lekooporna, klozapina, elektrowstrząsy, przezczaszkowa stymulacja magnetyczna, przezczaszkowa stymulacja elektryczna i deskryptorów czasowych: 1980-2017.

Wyniki: Najwięcej opracowań dotyczących możliwości zwiększenia skuteczności klozapiny poświecono terapii skojarzonej klozapina + zabiegi elektryczne. Wykazano w nich poprawę skuteczności w przypadku zastosowania tych dwóch metod równocześnie od 37.5 do $100 \%$. Jedyne jak dotąd badanie randomizowane również potwierdza skuteczność takiego postępowania. Pomimo opisywanych pojedynczych działań niepożądanych w postaci tachykardii czy przedłużonych napadów drgawkowych, większość badań wskazuje na bezpieczeństwo i skuteczność łącznego stosowania klozapiny oraz elektrowstrząsów. Przezczaszkowa stymulacja magnetyczna również okazuje się być bezpieczną metodą u pacjentów leczonych klozapiną. Jednak, aby potwierdzić skuteczność tego sposobu augmentacji, konieczne są dalsze badania. Dane dotyczące połączenia przezczaszkowej stymulacji elektrycznej z klozapiną, pochodzą jedynie z opisów przypadków i wymagają potwierdzenia w badaniach kontrolowanych.

Wnioski: Wyniki badań dotyczących możliwości zwiększania skuteczności klozapiny przy pomocy biologicznych niefarmakologicznych metod terapeutycznych wskazują na potencjalny korzystny wpływ tego typu metod w przełamywaniu super-oporności w schizofrenii. Połączenie klozapiny i EW można uznać za strategię najbardziej rekomendowaną spośród omó wionych metod leczenia. 


\section{Introduction}

Clozapine is an atypical antipsychotic drug, which due to the adverse events profile, is reserved for patients with treatment-resistant schizophrenia (TRS). Available data suggest that clozapine compared to other antipsychotics, is more effective in patients with TRS [1,2]. However, in $40-70 \%$ of patients treated with clozapine adequate response after this drug cannot be achieved[1,3,4], and this phenomenon is referred to as super-resistance [5]. In such cases, various augmentation attempts, both pharmacological and non-pharmacological, are undertaken.

So far combined treatment with clozapine and antipsychotic drugs, more rarely with mood stabilizers and others, has been widely discussed[4,6-9]. These include risperidone, aripiprazole, amisulpiride, sertindole, pimozide, ziprasidone, lamotrigine, antidepressants, omega-3 fatty acids [10].

It should be noted that treatment with clozapine only is sometimes associated with the risk of serious side effects (hematologic, cardiac or metabolic), which should be taken into account in choosing the appropriate method of augmentation [11]. This problem, among other things, prompts the search for non-pharmacological methods of augmentation with clozapine.

In comparison to studies on pharmacotherapy, much less space is devoted to combining clozapine with electroconvulsive therapy $(\mathrm{C}+\mathrm{ECT})$, transcranial direct current stimulation (tDCS) or transcranial magnetic stimulation (TMS) [11].

\section{Aim}

The aim of the work is to present biological, nonpharmacological augmentation methods of treatment with clozapine.

\section{Material and methods}

A review of the available literature in English and Polish on methods of non-pharmacological augmentation treatment with clozapine was made. PubMed database was searched using keywords: drug-resistant schizophrenia, clozapine, ECT, transcranial magnetic stimulation, transcranial electrical stimulation and time descriptors: 1980-2017.

\section{The efficacy and safety of ECT in combination with clozapine}

Electroconvulsive therapy (ECT) is probably the oldest method of treatment in psychiatry, a method that has survived to this day and is considered useful in patients with a variety of serious psychiatric disorders: single- and bipolar depression or schizophrenia [12-15].

In studies assessing the efficacy of ECT in schizophrenia this method was often used in combination with other antipsychotics and the safety and efficacy of this procedure was confirmed in patients with treatmentresistant schizophrenia (TRS) $[13,16]$.

As expected, due to the existing evidence of the utility of ECT in patients presenting the features of drug resistance, including resistance toclozapine, many authors have assessed the efficacy of combined use of clozapine and electroconvulsive therapy in patients with schizophrenia.

The first attempts of combined use of clozapine and ECT were undertaken more than 25 years ago [17], for the first time were reported a year later [18,19]. Fink [20] suggested that a positive response to treatment with clozapine in conjunction with ECT may be due to physiological changes that occur when these two methods are applied. According to Fink, ECT leads to an increased permeability of the blood-brain barrier, allowing larger molecules, such as clozapine, forbetterpenetration of the blood-brain and reaching more of its areas. Another likely mechanism is the potentiation of changes in the EEG caused by clozapine itself [20].

Recent research suggests that clozapine may potentiate GABAв neurotransmission in patients with schizophrenia, as evidenced by the elongation of the socalled Crescent Period (CSP) [21]. CSP elongation was also observed after successful treatment of schizophrenia by ECT and rTMS $[22,23]$. In connection with the evidence suggesting GABAвneurotransmissiondeficiency in schizophrenia [24], it seems reasonable to combine these stimulation methods with clozapine in patients resistant to antipsychotic therapy [11].

Over the decades, numerous data was collected on the combined use of clozapine and ECT. Initially these were only descriptions of clinical cases, followed by retrospective studies based on small patient groups and open-label studies. Recently data have been supplemented with the results of the first randomized doubleblind trial, which has increased the strength of evidence for such a treatment $[25,26]$.

One of the recent literature reviews on the combined use of clozapine and electroconvulsions includes 40 publications. It was created by searching the following databases: PubMed, Google Scholar and Science Direct, EMBASE and SCOPUS [25]. Unfortunately, only a single study of this review [25] included more than 10 patients receiving combined therapy [26-30].

The greater part of the available data on the combined use of clozapine and ECT relates to patients with schizophrenia. There are also few reports on the combined use of these methods in patients with schizoaffective disorder, bipolar disorder or major depressive episode. Single studies have described the use of clozapine and electroconvulsive therapy in patients with Parkinson's disease [31]. Regarding the patient profile, the majority of the reports included adult patients (19-65 years), 
sporadically 18 years or younger $[29,32]$ and those above 65 years. [31,33,34].

Reports evaluating the effectiveness of such treatment in patients with schizophrenia mainly concern patients who have been resistant to clozapine [27-30,35]. However, occasional reports of simultaneous use of both methods have been made [29,36,37].

Although in some studies aimed to objectify the assessment of response to the combined therapy rating scales such as the PANSS and BPRS were used, not many authors relied on standardized scales basing on subjective assessments [17,20,27,30,33].

In most published studies, ECT was considered after ineffective clozapine treatment. It was sometimes specified that patients were considered to be resistant to clozapine before ECT augmentation was considered [2629,33,38-40]. Occasionally, the use of clozapine after ECT was mentioned [32].

The dose of clozapine in these patients ranged between 50 and $800 \mathrm{mg} /$ day, and the number of treatments ranged from 8 to 35 , using the augumentationof ECT in some cases $[40,41]$.

In most cases, the authors used bilateral treatments. As for the response to the combination therapy, evidence from case reports suggest that this treatment leads to a reduction of psychopathological symptoms; however, only standardized clinical scales [33,42-44] were used in episodic reports.Due to the strength of the evidence, the only prospective, randomized, double-blind trial [26] should be discussed. Patients with TRS treated unsuccessfully with clozapine were divided into two groups: the first still being treated only with clozapine and the second one being treated with clozapine in combination with ECT. Treatments were applied for the first 4 weeks with a frequency of 3 treatments a week, and for the next four weeks - 2 treatments per week (a total of 20 ECT). Results showed that approximately $50 \%$ of patients in the C+ECT group responded positively, whereas in the clozapine-only group, no improvement was observed in either patient [26].

In general, the combination of clozapine and ECT seems to be effective against positive symptoms $[26,45]$. Results for negative symptoms remain ambiguous [26,28].

Studies have confirmed that combined use of clozapine and electroconvulsive therapy is associated with significantly shorter hospitalization time and that lower doses of clozapine may be used [25,37]. Shorter duration of current episode [45] and schizoaffective disorder [46] may be predictors for good combination of ECT and clozapine.

In comparison with other aspects of the combined use of clozapine and ECT, reports regarding the long-term outcomes of patients who received combined therapy were inconsistent. The reports, which mentioned the long-term effects, differed significantly in terms of dura- tion of follow-up after the last ECT, which ranged from 3 weeks to 24 months [25]. In one recent study of Grover et al. [47] published in 2017, the average follow-up was30 months, during which $72 \%$ of patients maintained improvement. In turn, Lally et al. [48] indicated in their review that in $32 \%(20 / 62)$ of the patients treated with the combination of ECT and clozapine, the recurrence of symptoms within weeks to months (range of observation from 3 to 468 weeks) after completion of the combined therapy occurred.

From the beginning of the combined use of clozapine and ECT, potential side effects were feared [49]. Clozapine may cause abnormalities in the EEG and its use is associated with a dose-dependent risk of epilepsy, so combined use of clozapine and electroconvulsive therapy may predispose to prolonged seizures during ECT [49] or spontaneous seizures after ECT $[10,49]$. In addition, prolonged epilepsy is seen in $1-2 \%$ of patients treated with ECT [51].The first reports of concomitant use of clozapine and ECT have also been observed against the epileptogenic effects of clozapine due to the development in some patients of prolonged seizures [32,53]. Over the years, however, available data indicate that the incidence of seizures is not high. [26,29]. Park and Lee [55] suggest that ECT can be used safely even in patients who have experienced clozapine-induced epilepsy. In summary, on the basis of available evidence, the risk of prolonged seizures may be slightly elevated [25].

Furthermore, the potent anticholinergic effect of clozapine may potentially exacerbate the adverse effects of electroconvulsions on cognitive function. In addition, clozapine causes accelerated heart rate and may contribute to QTc prolongation in patients with risk factors [52]. During ECT, transient overactivity of the sympathetic system is observed. The combination of clozapine and ECT may increase the risk of cardiac arrhythmias. $[11,49,53,54]$.

Cardiovascular adverse events resulting from the use of combination of ECT and clozapine have not been adequately investigated. Flamarique et al. [29] found tachycardia in 3 of 12 patients treated with ECT plus clozapine, and in 1 out of 16 patients receiving ECT plus other antipsychotics. The difference was not statistically significant. This may be due to the small sample size $(\mathrm{N}=$ 28). There are reports of serious cardiac complications such as supraventricular tachycardia and tachotsubo cardiomyopathy associated with combination of ECT and clozapine [34,56].

However, systematic research with strict monitoring of cardiovascular patients treated with clozapine, who are also undergoing ECT,is still missing, [11]. As mentioned above, some concerns about the combined use of electroconvulsionsterapy and clozapine were associated with the 
anticholinergic effect of clozapine, which could exacerbate the adverse effects of ECT on cognitive function.

In a study by Petrides et al. [26] unexpectedly, patients who received ECT and clozapine did not experience significantly higher global cognitive, executive or verbal cognitive deficits compared to patients treated with clozapine only. Data processing speed was the only cognitive function that was impaired in the ECT group, and this adverse outcome may be related to ECT alone [57], and not necessarily to the combination with clozapine.There are no controlled trials examining cognitive function in patients receiving ECT with clozapine in comparison with those who received only the ECT. Thus, although the safety of the ECT combination with clozapine in terms of cognitive functions cannot be ascertained, the limited available data suggest no increase in risk.

A systematic review of the study [48] published in 2016 reported undesirable effects in $14 \%$ of 166 subjects who received ECT and clozapine simultaneously. These included postictal confusion in six people, extended seizures in five respondents, temporary memory problems in four. Delirium occurred in three people and tachycardia in two. Aspiration pneumonia occurred in one person, as well as blood pressure surge. These data are similar to the incidence of complications in a population treated with ECT alone.

The effect of ECT on the cardiovascular system and cognitive functions, and the role of supporting ECT in patients receiving clozapine need to be clarified in protocols using methods with a lower risk of side effects on cognitive functions, such as unilateral ECT bifrontal, ultrashort impulses technique,LART (leftanterior, righttemporal) and FEAST (focal electrically administered seizure therapy) [11].

\section{The effectiveness and safety of rTMS combination with clozapine}

Transcranial magnetic stimulation (TMS) is one of the most recent physical therapy techniques used in psychiatry. TMS induces focal and noninvasive stimulation of the cortical surface of certain brain regions by sudden changes in the magnetic field generated by electromagnetic induction around the metal coil. The repetitive stimulation also causes a decrease or an increase in cortical excitability depending on the frequency of stimulation.A high stimulation frequency ( $>=5 \mathrm{~Hz}$ ) has a stimulating effect, and a low frequency $(<=1 \mathrm{~Hz}$ ) exerts an inhibitory effect on the regions of the cortex subjected to stimulation. Due to the focal nature of stimulation, it is usually directed to those regions of the cerebral cortex which are theoretically related to specific psychopathological symptoms [58].

This method is characterized by a number of advantages such as low invasiveness, painlessness, lack of inducing seizures and the need for anesthetic techniques use[59].
Originally, TMS was introduced into clinical practice as a diagnostic method in neuroscience (1985), and subsequently became a valuable tool in neurophysiological studies [59]. The results of numerous clinical trials have been published in the past two decades, confirming the therapeutic potential of this method in various psychiatric disorders (mainly depression and schizophrenia) [60].

In the early 1990s, magnetic stimulators were introduced to the market allowing for repetitiverapid-rate TMS (rTMS) [59.60].

The use of rTMS in patients with schizophrenia is associated with increased cortical crescent period and the potentiation of neurotransmission of GABA в [23.61]. The ability to potentiate glutamatergic neurotransmission was also attributed to clozapine. All this suggests that the combined use of rTMS and clozapine is justified by their synergistic effects on GABAв neurotransmission [11].

The rTMS is thought to be effective primarily in relation to auditory hallucinations and negative symptoms. Low-frequency rTMS used in left temporal lobe (Lt TPClefttemporo-parietal cortex) was used to treat patients with drug-resistant hallucinations [62]. High frequency rTMS is used to suppress the negative symptoms of schizophrenia over the left dorsolateral prefrontal cortex (DLPFC) and sometimes bilaterally (63).So far two randomized, placebo-controlled studies have been published on the efficacy of low-frequency rTMS applied to left temporo-parietal cortex in clozapine-treated patients with persistent auditory hallucinations [63,64]. The first of these included 11 patients with schizophrenia resistant to clozapine;rTMS over left sided temporomandibular cortex did not result in a difference in endpoint measurements compared to apparent stimulation [64].In a subsequent study of 17 patients with super-resistance, low frequency rTMS was used and a significant improvement in the intensity of general psychopathology was demonstrated. However, there was no difference in persistent auditory hallucinations [65]. The authors of these studies have suggested that improvement in general psychopathology is due to the distal cortical rTMS and to the augmentation of the inhibitory cortical effect.The effectiveness of this procedure for persistent auditory hallucinations in "clozapine-resistant" patients requires further evaluation in trials involving a larger number of patients.

Attempts to use various magnetic stimulation variants, such as low frequency stimulation over the left auditory cortex, have also been reported to be helpful in reducing hallucinations in 7 patients receiving clozapine [66]. In another report, continuous stimulation with the so-called "thetaburst" applied bilaterally over the temporal-parietal region for 9 weeks led to prolonged remission of persistent auditory hallucinations in clozapine-resistant schizophrenia patients [67]. However, in the recent large 
randomized trial,the patients with schizophrenia (some of whom received clozapine) in whom "thetaburst" stimulation was applied, have been shown to have no significant benefits in reducing the severity of persistent auditory hallucinations [68-70]. A review of the available research shows that the combination of clozapine with rTMS is not associated with the occurrence of side effects. For example, the case report on the effective use of rTMS as a maintenance treatment in a patient receiving clozapine showed no evidence of cognitive impairment or other serious adverse events [71].Although the efficacy of rTMS for negative symptoms only in the clozapine-resistant population has not been studied, randomized trials have also included patients treated with clozapine. The results of these studies are ambiguous [72-74].

Although the guidelines for the safe use of rTMSindicate that clozapine is a potential contraindication for the use of rTMS because of the possibility of a lowered threshold for seizures [75], however, in the cited papers on the combination of rTMS and clozapine there was no mention of seizures [72-74].

\section{Efficacy and safety of tDCScombination with clozapine}

One of the most well-known methods of post-seizure electrical stimulation, which has been discussed in numerous research papers, is transcranial direct current stimulation (tDCS) [76].

The tDCS is a non-invasive method of neurostimulation that uses a weak electrical current (1-2 mA) through two electrodes placed on the scalp. Cortical excitation is increased in the anode region and decreased in the cathode region [77]. A series of psychological tests and an EEG study were used to evaluate the effect of tDCS stimulation.There were no adverse events reported - also by MRI neurostructural examination, in which no morphological damage to nerve tissue was observed [78].

Authors of numerous studies report the effectiveness of this method in the treatment of depression [8083]. The key structure involved in the development of mood disorders is the left anterior dorsolateral cortex (LDLPFC) [84], hence this is the preferred stimulation region.Nitsche et al. [79] demonstrated that the efficacy of tDCS in depression was due to neuroplasticity.

Andrade [85] used tDCS with a cathode placed over the left TPC and an anode over the left DLPFC . It was used as a treatment for drug-resistant auditory verbal hallucinations $(\mathrm{AVH})$ and to alleviate the negative symptoms of schizophrenia. The tDCS was used twice daily to relieve AVH-resistant patients, as demonstrated by a randomized, placebo-controlled study [86]. However, the recent RCT (Randomized Controlled Trial), which used this method once daily using the same location, did not distinguish true and apparent stimulation, suggesting that the frequency of daytime stimulation influences the outcome [87].
The use of tDCS in "clozapine-resistant" schizophrenia was reported only in two case reports. In 53-year-old man with schizoaffective disorder and persistent AVH despite clozapine and ECT augmentation, tDCS was safely used following the protocol mentioned above [88]. The authors described the overall improvement, both in terms of positive and negative symptoms, in addition to relieving AVH. In the next case, a 24-year-old woman with a drug-resistant schizophrenia received tDCS for the same brain regions, resulting in significant improvements that continued for 3 years with supportive tDCS at home [84]. These reports provide preliminary evidence on the safety and efficacy of tDCS in the treatment of AVH in schizophrenia resistant to clozapine. The role of tDCS in clozapineresistant $\mathrm{AVH}$ requires confirmation in randomized trials.

\section{Other stimulation methods}

Attempts have also been made to use other new methods of stimulation, such as transcranial electrical stimulation of type tRNS (transcranial randomnoisestimulation), magnetic seizure therapy, or focused ultrasound, which are currently being tested [11].

The efficacy of these new techniques should be investigated in a variety of patient populations, including patients with schizophrenia, if they are to be used in their daily clinical practice [11].

Magnetic seizure therapy (MST) can induce more focused stimulation, which should be associated with a lower risk of cognitive side effects. There are already reports of its effectiveness in depressive disorders [89]. There is currently a clinical trial in patients with drugresistant schizophrenia [90].

The efficacy and safety of more recent transcranial magnetic stimulation techniques rTMS such as "thetaburst" stimulation and the role of more accurate localization techniques such as neuronavigation, as well as the usefulness of deep transcranial magnetic stimulation,require further research [11].

\section{Conclusions}

In summary, ECT seem like a good option as augmentation in patients resistant to clozapine therapy. Although a large number of data have already been collected confirming the validity and effectiveness of combining these two therapies, double-blind, randomized trials are rare in this group of patients [26]. Most data indicate the efficacy of clozapine used in combination with ECT to reduce the positive symptoms of [45] to remain doubtful with negative symptoms [28].

In the future, more emphasis should be placed on prospective studies and comparative research of group treated with a combination of clozapine and electroconvulsive therapy e.g. with the group treated with clozapine 
only, electroconvulsive only, or a combination of ECT and and other antipsychotics. Attention should also be paid to the assessment of long-term effects of treatment [24].

The rTMS can be safely combined with clozapine, but the effectiveness of such a combination for auditory hallucinations seems to be questionable. Further research is needed. The efficacy of transcranial electrical stimula- tion for auditory hallucinations resistant to clozapine therapy, requires confirmation in controlled studies. However, these two methods may be potentially valuable therapeutic options for the treatment of auditory hallucinations in patients with schizophrenia that are resistant to clozapine. if other interventions remain ineffective [11].

\section{Wstęp}

Klozapina jest atypowym lekiem przeciwpsychotycznym, który ze względu na profil działań niepożądanych, jest zarezerwowany dla pacjentów ze schizofrenią oporną na leczenie. Dostępne dane sugerują, że w porównaniu z innymi lekami przeciwpsychotycznymi, klozapina ma wyższą skuteczność u pacjentów ze schizofrenią lekooporną (TRS - treatment resistant schizophrenia) [1,2]. Pomimo tego, u 40-70\% pacjentów leczonych klozapiną nie uzyskuje się adekwatnej odpowiedzi po zastosowaniu tego leku $[1,3,4]$, a tego typu zjawisko określane bywa terminem super-oporności [5]. W takich wypadkach podejmowane są różne próby augmentacji, zarówno farmakologicznej jak i niefarmakologicznej.

Do tej pory dosyć szeroko omawiano leczenie skojarzone za pomocą klozapiny i leków przeciwpsychotycznych, rzadziej stabilizatorów nastroju czy innych [4,6-9]. Są to między innymi: risperidon, arypiprazol, amisulpryd, sertindol, pimozyd, zyprazydon, lamotrygina, leki przeciwdepresyjne, kwasy tłuszczowe omega-3 [10].

Należy pamiętać o tym, że samo leczenie klozapiną wiąże się z ryzykiem wystąpienia niekiedy poważnych objawów niepożądanych (hematologicznych, kardiologicznych czy metabolicznych), co należy brać pod uwagę w wyborze odpowiedniej metody augmentacji [11]. Problem ten, między innymi skłania do szukania innych niż farmakologiczne sposobów augmentacji leczenia klozapiną.

W porównaniu do opracowań dotyczących farmakoterapii znacznie mniej miejsca poświęcono kojarzeniu klozapiny z elektrowstrząsami (EW), przezczaszkową stymulacją elektryczną (tDCS) lub magnetyczną (TMS) [11].

\section{Cel}

Celem pracy jest prezentacja biologicznych niefarmakologicznych sposobów augmentacji leczenia klozapiną.

\section{Materiał i metoda}

Dokonano przeglądu dostępnej literatury w języku angielskim i języku polskim dotyczącej sposobów niefarmakologicznej augmentacji leczenia klozapiną. Korzystano z bazy PubMed, używając słów-kluczy: schizofrenia lekooporna, klozapina, elektrowstrząsy, przezczaszkowa stymulacja magnetyczna, przezczaszkowa stymulacja elektryczna oraz deskryptorów czasowych: 1980-2017.

\section{Skuteczność i bezpieczeństwo elektrowstrząsów w połączeniu z klozapiną}

Terapia elektrowstrząsowa (ECT - electroconvulsivetherapy) jest prawdopodobnie najstarszą metodą leczenia w psychiatrii, metodą, która przetrwała do dzisiaj i jest uważana za przydatną u pacjentów z różnymi poważnymi zaburzeniami psychicznymi: depresją jednoi dwubiegunową czy schizofrenią [12-15].

W badaniach oceniających skuteczność elektrowstrząsów w schizofrenii, często stosowano tę metodę w połączeniu z innymi lekami przeciwpsychotycznymi i potwierdzono bezpieczeństwo oraz skuteczność tego sposobu postępowania u pacjentów ze schizofrenią lekooporną $[13,16]$.

Zgodnie z oczekiwaniami, ze względu na istniejące dowody przydatności elektrowstrząsów u pacjentów przejawiających cechy lekooporności, w tym opornych na leczenie klozapiną, wielu autorów oceniło skuteczność łącznego stosowania klozapiny i elektrowstrząsów u pacjentów ze schizofrenią.

Pierwsze próby łącznego stosowania klozapiny i ECT podjęto ponad 25 lat temu [17], po raz pierwszy doniesiono o tym rok później $[18,19]$. Fink [20] zasugerował, że pozytywna odpowiedź na leczenie klozapiną w połączeniu z elektrowstrząsami może wynikać ze zmian fizjologicznych, które występują pod wpływem działania tych dwóch metod. Według Finka elektrowstrząsy prowadzą do zwiększenia przepuszczalności bariery krew-mózg, dzięki czemu większe cząsteczki, takie jak klozapina, są w stanie lepiej penetrować mózg i dotrzeć do większej liczby jego obszarów. Innym prawdopodobnym mechanizmem jest potencjalizacja zmian w EEG powodowanych przez samą klozapinę [20].

Najnowsze badania sugerują, że klozapina może potencjalizować neurotransmisję $\mathrm{GABA}_{\mathrm{B}} \mathrm{u}$ pacjentów ze schizofrenią, czego dowodem jest wydłużenie tzw. korowego okresu ciszy (CSP) [21]. Wydłużenie CSP było obserwowane również po udanym leczeniu schizofrenii za pomocą ECT oraz rTMS [22,23]. W połączeniu z dowodami sugerującymi deficyt neurotransmisji GABAв w schizofrenii [24], zasadne wydaje się łączenie tych metod stymulacji z klozapiną, u pacjentów opornych na leczenie przeciwpsychotyczne [11]. 
W ciągu kilkudziesięciu lat zgromadzono wiele danych dotyczących łącznego stosowania klozapiny oraz elektrowstrząsów. Początkowo były to jedynie opisy przypadków klinicznych, następnie badania retrospektywne oparte na niewielkich grupach pacjentów i badania otwarte. Ostatnio dane zostały uzupełnione o wyniki pierwszego badania randomizowanego z podwójnie ślepą próbą, co zwiększyło siłę dowodów na zasadność takiego leczenia [25,26].

Jeden z nowszych przeglądów literatury dotyczący łącznego stosowania klozapiny i elektrowstrząsów, obejmuje 40 publikacji. Powstał on na podstawie przeszukania następujących baz danych: PubMed, Google Scholar i Science Direct, EMBASE i SCOPUS [25]. Niestety jedynie pojedyncze badania ze wspomnianego przeglądu [25] obejmowały więcej niż 10 pacjentów otrzymujących terapię skojarzoną [26-30].

Większa część dostępnych danych na temat łącznego stosowania klozapiny i ECT dotyczy pacjentów z rozpoznaniem schizofrenii. Istnieje również niewiele doniesień na temat skojarzonego zastosowania tych metod u pacjentów z zaburzeniem schizoafektywnym, zaburzeniem afektywnym dwubiegunowym czy epizodem dużej depresji. Pojedyncze prace opisywały użycie klozapiny i elektrowstrząsów u pacjentów z psychozą w przebiegu choroby Parkinsona [31]. Odnośnie profilu pacjentów, większość doniesień obejmowała pacjentów dorosłych (19-65 lat), sporadycznie 18-letnich lub młodszych [29,32] oraz tych powyżej 65 r.ż. [31,33,34].

Doniesienia oceniające skuteczność takiego postępowania u pacjentów ze schizofrenią, w przeważającej części dotyczyły chorych, którzy byli oporni na klozapinę [27-30,35]. Jednakże pojawiły się sporadyczne doniesienia o jednoczasowym zastosowaniu obu metod [29,36,37].

Chociaż w niektórych pracach w celu obiektywizacji oceny odpowiedzi na leczenie skojarzone wykorzystano skale oceny takie jak PANSS czy BPRS, wielu autorów nie oparło się na standaryzowanych skalach bazując na subiektywnych ocenach. [17,20,27,30,33]

W większości opublikowanych badań, elektrowstrząsy były brane pod uwagę po nieskutecznym leczeniu klozapiną. Niekiedy precyzowano, że pacjenci zostali uznani za opornych na klozapinę zanim zaczęto rozważać augmentację za pomocą ECT [26-29,33,38-40]. Sporadycznie zaś wspominano o użyciu klozapiny po ECT [32].

Dawka klozapiny zastosowana u tych pacjentów wahała się pomiędzy 50 a $800 \mathrm{mg} / \mathrm{d}$, a liczba zabiegów wynosiła od 8 do 35 , z zastosowaniem podtrzymujących ECT w niektórych przypadkach $[40,41]$.

W większości doniesień autorzy stosowali zabiegi dwuskroniowo. Jeśli chodzi o odpowiedź na leczenie skojarzone, dowody pochodzące z opisów przypadków sugerują, że leczenie to prowadzi do redukcji objawów psychopatologicznych; jednakże tylko w epizodycznych doniesieniach użyto wystandaryzowanych skali klinicznych [33,42-44].

Ze względu na siłę dowodów, szerzej należy omówić jedyne prospektywne randomizowane badanie z podwójnie ślepą próbą [26]. Pacjenci ze schizofrenią lekooporną leczeni bez efektu klozapiną zostali podzielni na dwie grupy: pierwsza leczona nadal tylko klozapiną oraz druga, leczona klozapiną $\mathrm{w}$ połączeniu $\mathrm{z}$ elektrowstrząsami. Zabiegi były stosowane przez pierwsze 4 tygodnie z częstotliwością 3 zabiegi w tygodniu, a przez kolejne 4 tygodnie 2 zabiegi w tygodniu (w sumie 20 ECT). Wyniki wykazały, że około 50 \% pacjentów z grupy leczonej kombinacją klozapiny i elektrowstrząsów odpowiedziało pozytywnie, podczas gdy $\mathrm{z}$ grupy leczonej wyłącznie klozapiną u żadnego z badanych nie obserwowano poprawy [26].

Generalnie można podsumować, że kombinacja klozapiny i elektrowstrząsów wydaje się być skuteczna wobec objawów pozytywnych $[26,45]$. Wyniki odnośnie objawów negatywnych pozostają niejednoznaczne [26,28].

Badania potwierdzają, że łączne stosowanie klozapiny i elektrowstrząsów wiąże się z istotnie krótszym czasem hospitalizacji oraz umożliwia stosowanie mniejszych dawek klozapiny [25,37]. Krótszy czas trwania aktualnego epizodu [45] oraz zaburzenie schizoafektywne [46] mogą być predyktorami dobrej odpowiedzi na stosowanie kombinacji elektrowstrząsów i klozapiny.

W porównaniu z innymi aspektami łącznego stosowania klozapiny i elektrowstrząsów, doniesienia odnośnie długoterminowych wyników leczenia pacjentów, którzy otrzymywali leczenie skojarzone, były niespójne. Raporty, które wspomniały o długoterminowych efektach, różniły się znacząco w zakresie trwania obserwacji po ostatnim ECT, który wahał się od 3 tygodni do 24 miesięcy [25]. W jednym z ostatnich badań Grovera i wsp. [47] opublikowanym w 2017 roku, średni okres obserwacji wynosił 30 miesięcy, podczas których $72 \%$ badanych utrzymało poprawę. Z kolei Lally i wsp. [48] wskazali w swoim przeglądzie badań, że u 32\% (20/62) pacjentów leczonych kombinacją elektrowstrząsów i klozapiny doszło do nawrotu objawów w przeciągu tygodni do miesięcy (zakres obserwacji od 3 do 468 tygodni) po ukończeniu łączonej terapii.

Od początku prób łącznego stosowania klozapiny i ECT obawiano się potencjalnych skutków ubocznych [49]. Klozapina może powodować nieprawidłowości w EEG i jej stosowanie wiąże się z zależnym od dawki ryzykiem napadów padaczkowych, dlatego łączne zastosowanie klozapiny i elektrowstrząsów może predysponować do wydłużonych napadów padaczkowych w czasie trwania ECT [49] lub wystąpienia spontanicznych napadów padaczkowych po ECT $[10,49]$. Poza tym przedłużone napady padaczkowe obserwuje się u 1-2\% pacjentów leczonych elektrowstrząsami [51]. Pierwsze doniesienia dotyczące równo- 
czesnego stosowania klozapiny i ECT również przestrzegały przed działaniem epileptogennym klozapiny ze względu na pojawienie się u niektórych pacjentów przedłużonych napadów drgawkowych [32,53]. Jednak na przestrzeni lat, dostępne dane wskazują, że częstość występowania napadów drgawkowych nie jest wysoka. [26,29]. Park i Lee [55] sugerują, że elektrowstrząsy mogą być stosowane bezpiecznie nawet u pacjentów, u których wystąpiły napady padaczkowe indukowane klozapiną. Podsumowując, na podstawie dostępnych dowodów można stwierdzić, że ryzyko przedłużonych napadów padaczkowych może być jedynie nieznacznie podwyższone [25].

Ponadto silny efekt antycholinergiczny klozapiny może potencjalnie zaostrzać niekorzystny wpływ elektrowstrząsów na funkcje poznawcze. Dodatkowo klozapina powoduje przyspieszenie akcji serca i może przyczyniać się do wydłużenia odcinka QTc u pacjentów z czynnikami ryzyka [52]. Podczas ECT obserwujemy przejściową nadaktywność układu współczulnego. Kombinacja klozapiny i ECT może w związku z tym podnosić ryzyko zaburzeń rytmu serca. [11,49,53,54].

Działania niepożądane ze strony układu krążenia wynikające ze stosowania kombinacji ECT- klozapina nie zostały wystarczająco dokładnie zbadane. W badaniu Flamarique i wsp. [29] stwierdzono częstoskurcz u 3 z 12 pacjentów leczonych ECT łącznie z klozapiną, oraz u 1 z 16 pacjentów otrzymujących ECT łącznie z innym lekiem antypsychotycznym. Różnica nie była istotna statystycznie. Może się to wiązać z małą liczebnością grupy badanej $(\mathrm{N}=28)$. Istnieją opisy przypadków donoszących o poważnych powikłaniach sercowych, takich jak częstoskurcz nadkomorowy czy kardiomiopatia Takotsubo, związanych z kombinacją ECT- klozapina $[34,56]$.

Nadal brakuje jednak systematycznych badań ze ścisłym monitoringiem krążenia u pacjentów leczonych klozapiną, którzy dodatkowo są poddawani ECT [11]. Jak wspomniano powyżej pewne obawy łącznego stosowania elektrowstrząsów i klozapiny wiązały się z efektem antycholinergicznym klozapiny, co mogłoby zaostrzać niekorzystny wpływ elektrowstrząsów na funkcje poznawcze.

W badaniu przeprowadzonym przez Petrides i wsp. [26] nieoczekiwanie, pacjenci, którzy otrzymywali ECT i klozapinę nie doświadczyli znacząco wyższych globalnych deficytów funkcji poznawczych, wykonawczych czy związanych z pamięcią werbalną lub wzrokową, w porównaniu do pacjentów leczonych wyłącznie klozapiną. Prędkość przetwarzania informacji była jedyną funkcją poznawczą, która została zaburzona w grupie otrzymującej ECT, a ten niekorzystny wynik może mieć związek z samymi ECT [57], a niekoniecznie z kombinacją z klozapiną. Nie ma żadnych kontrolowanych prób badających funkcje poznawcze u pacjentów otrzymujących ECT z klozapiną w zestawieniu z tymi, którzy otrzymywali wyłącznie ECT.
Tak więc, chociaż nie można stwierdzić bezpieczeństwa stosowania kombinacji ECT- klozapina w zakresie funkcji poznawczych, ograniczone dostępne dane sugerują brak wzrostu ryzyka.

W opublikowanym w 2016 roku systematycznym przeglądzie badań [48] opisano objawy niepożądane u 14\% z 166 badanych, u których stosowano równocześnie ECT i klozapinę. Obejmowały one dezorientację ponapadową u sześciu osób, przedłużony napad padaczkowy u pięciu badanych, przejściowe problemy z pamięcią u czterech. Majaczenie wystąpiło u trzech osób, częstoskurcz u dwóch. Zachłystowe zapalenie płuc wystąpiło u jednej osoby, podobnie jak skok ciśnienia tętniczego. Dane te są zbliżone do częstości występowania powikłań w populacji leczonej wyłącznie elektrowstrząsami.

Wpływ ECT na układ krążenia i funkcje poznawcze oraz rola podtrzymujących ECT u pacjentów otrzymujących klozapinę wymagają doprecyzowania protokołów z zastosowaniem metod o mniejszym ryzyku działań niepożądanych ze strony funkcji poznawczych, takich jak ECT jednostronne, dwuczołowe, techniką ultrakrótkotrwałych impulsów, LART (leftanterior, righttemporal) i FEAST (ocal electrically administered seizure therapy) [11].

\section{Skuteczność i bezpieczeństwo łączenia rTMS z klozapiną}

Przezczaszkowa stymulacja magnetyczna (TMS transcranial magnetic stimulation) należy do jednej $\mathrm{z}$ najnowszych technik leczenia fizykalnego stosowanych w psychiatrii. TMS wywołuje ogniskową i nieinwazyjną stymulację powierzchni kory pewnych regionów mózgu przez nagłe zmiany pola magnetycznego, wytwarzanego przez indukcję elektromagnetyczną wokół metalowej cewki. Powtarzalna stymulacja ma także powodować wzrost albo spadek pobudliwości kory w zależności od częstotliwości stymulacji. Wysoka częstotliwość stymulacji (>= $5 \mathrm{~Hz}$ ) ma efekt pobudzający, a niska częstotliwość (<= $1 \mathrm{~Hz}$ ) wywiera efekt hamujący na regiony kory poddawane stymulacji. Z powodu ogniskowej natury stymulacji, jest ona zwykle nakierowywana na te regiony kory mózgu, które teoretycznie związane są z konkretnymi objawami psychopatologicznymi [58].

Metoda ta charakteryzuje się szeregiem zalet, takich jak mała inwazyjność, bezbolesność, brak wywoływania efektu drgawkowego czy konieczności zastosowania technik anestezjologicznych [59].

Pierwotnie TMS została wprowadzona do praktyki klinicznej, jako metoda diagnostyczna w neurologii (1985), następnie stała się cennym narzędziem w badaniach neurofizjologicznych [59]. W ostatnich dwóch dekadach opublikowano wyniki licznych badań klinicznych potwierdzających potencjał terapeutyczny tej metody w różnych zaburzeniach psychicznych (głównie depresji i schizofrenii) [60]. 
Na początku lat 90-tych XX wieku na rynku pojawiły się stymulatory magnetyczne pozwalające na tzw. wysokoczęstotliwą stymulację (rTMS - repetitiverapid-rate TMS) $[59,60]$.

Zastosowanie rTMS u pacjentów ze schizofrenią wiąże się z wydłużeniem korowego okresu ciszy oraz potencjalizacją neurotransmisji GABAв [23,61]. Zdolność do potencjalizacji neurotransmisji glutaminergicznej przypisywano również klozapinie. Wszystko to wskazuje, że próba łącznego stosowania rTMS i klozapiny ma uzasadnienie wynikające $\mathrm{z}$ synergistycznych ich działań na neurotransmisję GABAв [11].

Uważa się, że rTMS może być skuteczna przede wszystkim w odniesieniu do halucynacji słuchowych oraz objawów negatywnych. rTMS niskiej częstotliwości stosowana w obszarze lewej kory skroniowo-ciemieniowej (Lt TPC- left temporoparietal cortex) była wykorzystywana w leczeniu pacjentów z halucynacjami słuchowymi opornymi na farmakoterapię [62]. Do złagodzenia negatywnych objawów schizofrenii wykorzystuje się rTMS wysokiej częstotliwości stosowaną nad lewą korą przedczołową grzbietowo-boczną (DLPFC - dorsolateral prefrontal cortex), a czasami obustronnie [63]. Do tej pory opublikowano dwa randomizowane badania, kontrolowane placebo, dotyczące skuteczności rTMS niskiej częstotliwości stosowanej nad lewą korą skroniowociemieniową u pacjentów leczonych klozapiną, z przetrwałymi halucynacjami słuchowymi [63,64]. Pierwsze z nich obejmowało 11 pacjentów ze schizofrenią oporną na klozapinę, rTMS nad lewą korą skroniowociemieniową nie skutkowało różnicą $\mathrm{w}$ końcowych pomiarach $\mathrm{w}$ porównaniu do pozornej stymulacji [64]. W późniejszym badaniu obejmującym 17 pacjentów z superopornością, stosowano rTMS niskiej częstotliwości i wykazano znaczącą poprawę w zakresie nasilenia ogólnej psychopatologii. Jednak nie zaobserwowano różnicy w przypadku przetrwałych halucynacji słuchowych [65]. Autorzy tych prac sugerowali, że poprawa w zakresie nasilenia ogólnej psychopatologii jest skutkiem odległego efektu korowego rTMS oraz wzmocnienia hamującego efektu korowego. Skuteczność tej procedury wobec przetrwałych halucynacji słuchowych u pacjentów "klozapinoopornych" wymaga dalszej oceny w próbach obejmujących większą liczbę badanych.

Podejmowano również próby stosowania różnych wariantów stymulacji magnetycznej np. stymulacja niskiej częstotliwości nad lewą korą słuchową okazała się być pomocna $\mathrm{w}$ redukowaniu halucynacji u 7 pacjentów otrzymujących klozapinę [66]. W innym doniesieniu, ciągła stymulacja tzw. "theta burst" stosowana obustronnie nad obszarem skroniowo-ciemieniowym przez 9 tygodni doprowadziła do wydłużenia remisji w zakresie przetrwałych halucynacji słuchowych, u pacjentów ze schizofrenią oporną na klozapinę [67]. Jednakże, w ostatnim dużym badaniu randomizowanym u pacjentów ze schizofrenią (z których część otrzymywała klozapinę), u których zastosowano stymulację "theta burst", nie wykazano znaczących korzyści w zmniejszaniu nasilenia przetrwałych halucynacji słuchowych [68-70]. Z przeglądu dostępnych badań wynika, iż połączenie rTMS z klozapiną nie wiąże się $\mathrm{z}$ występowaniem działaniach niepożądanych. Na przykład opis przypadku dotyczący skutecznego zastosowania rTMS, jako leczenia podtrzymującego u pacjenta otrzymującego klozapinę nie wykazał żadnych objawów upośledzenia funkcji poznawczych lub innych poważnych zdarzeń niepożądanych [71]. Chociaż nie badano skuteczności rTMS w zakresie objawów negatywnych wyłącznie w populacji opornej na klozapinę, opublikowane badania randomizowane obejmowały również pacjentów leczonych klozapiną. Wyniki tych badań pozostają niejednoznaczne [72-74].

Choć z wytycznych dotyczących bezpiecznego stosowania rTMS wynika, że klozapina stanowi potencjalne przeciwwskazanie dla użycia rTMS z powodu możliwości obniżenia progu drgawkowego [75]. Jednakże w cytowanych publikacjach dotyczących kombinacji rTMS i klozapiny nie było wzmianki o przypadkach napadów drgawkowych [72-74].

\section{Skuteczność i bezpieczeństwo łączenia tDCS z klozapiną}

Jedną z najbardziej znanych metod poddrgawkowej stymulacji elektrycznej, której poświęcono liczne prace badawcze, jest przezczaszkowa stymulacja stałoprądowa lub stymulacja prądem stałym (tDCS - transcranialdirectcurrentstimulation) [76].

tDCS jest nieinwazyjną metodą neurostymulacji, która wykorzystuje przepływ słabego prądu elektrycznego (1-2 mA) przez dwie elektrody umieszczone na skórze głowy. Pobudliwość korowa jest zwiększona w okolicy anody i zmniejszona w okolicy katody [77]. W celu oceny efektu stymulacji tDCS, posłużono się serią badań psychologicznych oraz badaniem EEG. Nie stwierdzono żadnych działań niepożądanych- również za pomocą badania neurostrukturalnego MRI, w którym nie obserwowano uszkodzeń morfologicznych tkanki nerwowej [78].

Autorzy licznych badań donoszą o skuteczności tej metody w leczeniu depresji [80-83]. Za kluczową strukturę uczestniczącą $\mathrm{w}$ powstawaniu zaburzeń nastroju uznaje się lewą okolicę grzbietowo-boczną kory przedczołowej (LDLPFC) [84], stąd jest to preferowany obszar stymulacji. Z kolei Nitsche i wsp. [79] wykazali, iż skuteczność tDCS w depresji wynika ze zjawiska neuroplastyczności.

Andrade [85] zastosował tDCS z katodą umieszczoną nad lewą TPC i anodą umieszczoną nad lewą DLPFC zastosowano jako leczenie opornych na farmakoterapię omamów słuchowych (AVH - audi tory verbal hallucina- 
tions), oraz w celu złagodzenia negatywnych objawów schizofrenii. tDCS zastosowana dwa razy dziennie powodowała łagodzenie opornych na leczenie AVH, co zostało dowiedzione $w$ randomizowanym, kontrolowanym placebo badaniu [86]. Jednakże, ostatnie RCT (randomized controlled trial), w którym metodę tę zastosowano raz dziennie wykorzystując tę samą lokalizację, nie pozwoliło na odróżnienie prawdziwej i pozornej stymulacji, co wskazuje, że częstotliwość stymulacji w ciągu dnia wpływa na wyniki [87].

O zastosowaniu tDCS w "klozapinoopornej" schizofrenii donoszono jedynie $\mathrm{w}$ dwóch opisach przypadków. U 53-letniego mężczyzny z zaburzeniem schizoafektywnym i przetrwałymi AVH pomimo klozapiny i podtrzymującej ECT, tDCS stosowano bezpiecznie stosując się do wspomnianego powyżej protokołu [88]. Autorzy opisywali ogólną poprawę, zarówno w zakresie pozytywnych, jak i negatywnych objawów, ponadto złagodzenie nasilenia AVH. W kolejnym przypadku, 24-letnia kobieta ze schizofrenią lekooporną otrzymywała tDCS na te same rejony mózgowia, co poskutkowało znaczącą poprawą, która utrzymywała się przez kolejne 3 lata z podtrzymującą tDCS w miejscu zamieszkania [84]. Doniesienia te dostarczają wstępnych dowodów na bezpieczeństwo i skuteczność tDCS w leczeniu AVH w schizofrenii opornej na klozapinę. Rola tDCS w AVH opornych na klozapinę wymaga potwierdzenia $\mathrm{w}$ badaniach randomizowanych.

\section{Inne metody stymulacji}

Podejmowano również próby stosowania innych, nowszych metody stymulacji, takich jak przezczaszkowa stymulacja prądem elektrycznym typu tRNS (transcranial random noise stimulation), metod wstrząsów magnetycznych, czy zogniskowanych ultradźwięków, które są obecnie testowane [11].

Skuteczność tych nowych technik powinna być zbadana $\mathrm{w}$ różnych populacjach pacjentów, między innymi u pacjentów z lekooporną schizofrenią, jeżeli miałyby w przyszłości znaleźć zastosowanie w codziennej praktyce klinicznej [11].

Terapia wstrząsów magnetycznych (MST), może indukować bardziej zogniskowaną stymulację, co powinno wiązać się z mniejszym ryzykiem poznawczych efektów ubocznych. Istnieją już pewnie doniesienia co do jej skuteczności w zaburzeniu depresyjnym [89]. Aktualnie prowadzone jest badanie kliniczne w grupie pacjentów z lekooporną schizofrenią [90].

Skuteczność i bezpieczeństwo nowszych technik przezczaszkowej stymulacji magnetycznej - rTMS takich jak stymulacja „theta burst”, oraz rola bardziej dokładnych technik lokalizacji np. przy zastosowaniu neuronawigacji, wymaga dalszych badań, podobnie jak przydat- ność głębokiej przezczaszkowej stymulacji magnetycznej [11].

\section{Podsumowanie}

Podsumowując, elektrowstrząsy wydają się dobrym rozwiązaniem, jako augmentacja u pacjentów opornych na terapię klozapiną. Mimo, że zebrano już znaczną ilość danych potwierdzających zasadność i skuteczność łączenia tych obu metod terapeutycznych, to jednak badania randomizowane z podwójnie ślepą próbą należą do rzadkości w tej grupie pacjentów [26]. Najwięcej danych wskazuje na skuteczność klozapiny stosowanej łącznie z elektrowstrząsami w redukcji objawów pozytywnych [45], pozostając wątpliwą wobec objawów negatywnych [28].

W przyszłości należy położyć większy nacisk na badania prospektywne oraz badania porównawcze grupy leczonej kombinacją klozapiny i elektrowstrząsów np. z grupa leczoną wyłącznie klozapiną, wyłącznie elektrowstrząsami, czy też kombinacją elektrowstrząsów i innych leków antypsychotycznych. Powinno się skupić również na ocenie długotrwałych skutków leczenia [24].

rTMS może być bezpiecznie łączona z klozapiną, jednak skuteczność takiego połączenia wobec halucynacji słuchowych wydaje się być wątpliwa. Konieczne są dalsze badania. Skuteczność przezczaszkowej stymulacji elektrycznej wobec halucynacji słuchowych opornych na leczenie klozapiną wymaga potwierdzenia w badaniach kontrolowanych. Jednak te dwie ostatnie metody mogą stanowić potencjalnie wartościową opcję terapeutyczną w leczeniu halucynacji słuchowych u pacjentów ze schizofrenią, opornych na klozapinę, jeżeli inne interwencje pozostają nieskuteczne [11].

\section{Conflict of interest}

The authors have declared no conflict of interest.

\section{References:}

1. Kane JM, Honigfeld G, Singer J, Meltzer H. Clozapine in treatmentresistant schizophrenics. Psychopharmacol Bull 1988;24:62-67.

2. Melzer HY. Defining treatment refractoriness in schizophrenia. Schizophr Bull 1990;16:563-565

3. Meltzer HY. Dimensions of outcome with clozapine. $\mathrm{Br}$ J Psychiatry Suppl. 1992; (17):46-53

4. Sommer IE, Begemann MJH, Temmerman A, Leucht $\mathrm{S}$. Pharmacological Augmentation Strategies for Schizophrenia Patients With Insufficient Response to Clozapine: A Quantitative Literature Review. Schizophr. Bull. 38(5), 1003-1011 (2012)

5. Henna Neto J, Elkis $\mathrm{H}$. Clinical aspects of super-refractory schizophrenia: A 6-month cohort observational study. Rev Bras Psiquiatr. 2007 Sep;29(3):228-32

6. Sinclair D, Adams CE. Treatment resistant schizophrenia: a comprehensive survey of randomised controlled trials. BMC Psychiatry 2014;14:253-260 
7. Miyamoto S, Jarskog LF, Fleischhacker WW. New therapeutic approaches for treatment-resistant schizophrenia: a look to the future. J. Psychiatr. Res. 58, 1-6 (2014)

8. Muscatello MRA, Bruno A, De Fazio P, Segura-Garcia C, Pandolfo G, Zoccali R. Augmentation strategies in partial responder and/or treatment-resistant schizophrenia patients treated with clozapine. Expert Opin. Pharmacother. 15(16), 2329-2345 (2014)

9. Miyamoto S, Jarskog LF, Fleischhacker WW. Schizophrenia: when clozapine fails.CurrOpin Psychiatry. 2015 May;28(3):243-8

10. Vayisoğlu S, Yağcioğlu AE. Augmentation strategies in patients with schizophrenia who show partial response to clozapine treatment. Turk PsikiyatriDerg 2014;25(3):201-211

11. Arumugham SS, Thirthalli J, Andrade C. Efficacy and safety of combining clozapine with electrical or magnetic brain stimulation in treatment-refractory schizophrenia Expert Rev ClinPharmacol. 2016 Sep;9(9):1245-52

12. Chanpattana W, Kunigiri G, Kramer BA, Gangadhar BN. Survey of the practice of electroconvulsive therapy in teaching hospitals in India. JECT 2005;21:100-104

13. Braga RJ, Petrides G. The combined use of electroconvulsive therapy and antipsychotics in patients with schizophrenia. J ECT 2005;21:75-83

14. Chanpattana W, Andrade C. ECT for treatment-resistant schizophrenia: a response from the far East to the UK. NICE report. J ECT 2006;22:4-12

15. Chanpattana W, Kramer BA, Kunigiri G, Gangadhar BN, Kitphati R, Andrade C. A survey of the practice of electroconvulsive therapy in Asia. J ECT 2010;26:5-10

16. Rayikanti R, Lentowicz I, Birbur B, Li L. Combined Antipsychotics and Electroconvulsive Therapy in an Acutely Psychotic Patient with Treatment-resistant Schizophrenia. Psychopharmacol Bull. 2017 May 15;47(2): 57-62

17. Fink M. Clozapine and electroconvulsive therapy. Arch Gen Psychiatry 1990;47:290-291

18. Klapheke MM. Clozapine, ECT, and Schizoaffective disorder, bipolar type. Convuls Ther 1991;7:36-39

19. Klapheke MM. Follow-up on clozapine and ECT. ConvulsTher 1991;7:303-305

20. Fink M. ECT and clozapine in schizophrenia. J ECT 1998;14:223226

21. Kaster TS, de Jesus D, Radhu N, Farzan F, Blumberger DM, Rajji TK et al. Clozapine potentiation of GABA mediated cortical inhibition in treatment resistant schizophrenia. Schizophr. Res. 165(2-3), 157-162 (2015)

22. Langguth B, Eichhammer P, Zowe M, Marienhagen J, Spiessl H, Hajak G.

Neuronavigated transcranial magnetic stimulation and auditory hallucinations in a Schizophrenic patient: Monitoring of neurobiological effects. Schizophr. Res. 84(1), 185-186 (2006)

23. Přikryl R, Ustohal L, Kucerová HP, Cesková E. Effect of electroconvulsive therapy on cortical excitability in a patient with long-term remission of schizophrenia: a transcranial magnetic stimulation study. J. ECT. 27(1), e9-11 (2011)

24. Daskalakis ZJ, George TP. Clozapine, GABA(B), and the treatment of resistant schizophrenia. Clin. Pharmacol. Ther. 86(4), 442-446 (2009)

25. Grover S, Hazari N, Kate N. Combined use of clozapine and ECT: a review. ActaNeuropsychiatr. 2015 Jun;27(3):131-42

26. Petrides G, Malur C, Braga RJ, Bailine SH, Schooler NR, Malhotra AK. Electroconvulsive therapy augmentation in clozapineresistant schizophrenia: a prospective, randomized study. Am J Psychiatry 2015;172:52-58

27. Frankenberg FR, Suppes T, Mclean PE. Combined clozapine and electroconvulsive therapy. Convulsive Ther 1993;9:176-180
28. Kho KH, Blansjaar BA, De Vries S, Babuskova D, Zwinderman AH, Linszen DH. Electroconvulsive therapy for the treatment of clozapine nonresponders suffering from schizophrenia: an open label study. Eur Arch Psychiatry ClinNeurosci 2004;254:372-379

29. Flamarique I, Castro-Fornieles J, Garrido JM, de la Serna E, Pons A, Bernardo $\mathrm{M}$ et al. Electroconvulsive therapy and clozapine in adolescents with schizophrenia spectrum disorders: is it a safe and effective combination? J ClinPsychopharmacol 2012;32:756-766.

30. Kristensen D, Hageman I, Bauer J, JØrgensen MB, Correll CU. Antipsychotic polypharmacy in a treatment-refractory schizophrenia population receiving adjunctive treatment with electroconvulsive therapy. J ECT 2013;29:271-276

31. Factor SA, Molho ES, Brown DL. Combined clozapine and electroconvulsive therapy for the treatment of drug-induced psychosis in Parkinson's disease. J Neuropsychiatry Clin Neurosci 1995; 7:304-307

32. Bloch Y, Pollack M, Mor I. Should the administration of ECT during clozapine therapy be contraindicated? Br J Psychiatry 1996;169:253-254

33. Kales HC, Dequardo JR, Tandon R. Combined electroconvulsive therapy and clozapine in treatmentresistant schizophrenia. ProgNeuropsychopharmacolBiol Psychiatry 1999;23:547-556

34. Beale MD, Prichett JT, Kellner CH. Supraventricular tachycardia in a patient receiving ECT, clozapine, and caffeine. ConvulsTher 1994;10:228-231

35. Cardwell BA, Nakai B. Seizure activity in combined clozapine and ECT: a retrospective view. ConvulsTher 1995;11:110-113

36. Masoudzadeh A, Khailian AR. Comparative study of clozapine, electroshock and the combination of ECT with clozapine in treatment-resistant schizophrenic patients. Pak J BiolSci 2007;10:4287-4290

37. Koen L, Van den Berg CE, Niehaus DJH. Combining ECT and clozapine in the treatment of clozapine-refractory schizophrenia and schizoaffective disorder - a pilot study. S AfrJ Psychiatry 2008;14:131-135

38. Kales HC, Tandon R, Dequqrdo JR, Maixner D, Jibson M, Becks L. Combined electroconvulsive therapy and clozapine in schizophrenia. J Clin Psychiatry 1995;37:678

39. James DV, Gray NS. Elective combined electroconvulsive and clozapine therapy. IntClinPsychopharmacol 1999; 14:69-72

40. Bannour S, Bouhlel S, Krir MW, Amamou B, Ben Nasr S, El Kissi Y et al. Combination of maintenance electroconvulsive therapy and clozapine in treating a patient with refractory schizophrenia. J ECT 2014;30:e29-e30

41. Vowels EC, Hitturlingappa S, Bastiampillai T. Combination clozapine and electroconvulsive therapy in a patient with schizophrenia and comorbid intellectual disability. Aust N Z J Psychiatry 2014;48:689-690

42. Banatov R, Sirota P, Megged S. Neuroleptic-resistant schizophrenia treated with clozapine and ECT. ConvulsTher 1996;12:117-121

43. Husni M, Haggarty J, Peat C. Clozapine does not increase ECTseizure duration. Can J Psychiatry 1999;44:190-191

44. Biedermann F, Pfaffenberger N, Baumgartner S, Kemmler G, Fleischhacker WW, Hofer A. Combined clozapine and electroconvulsive therapy in clozapine-resistant schizophrenia: clinical and cognitive outcomes. J ECT 2011;27:e61-e62

45. Pawełczyk T, Kołodziej-Kowalska E, Pawełczyk A, RabeJabłońska J. Effectiveness and clinical predictors of response to combined ECT and antipsychotic therapy in patients with treatment-resistant schizophrenia and dominant negative symptoms. Psychiatry Res. 220(1-2), 175-180 (2014) 
46. Gazdag G, Kocsis-Ficzere N, Tolna J. The augmentation of clozapine treatment with electroconvulsive therapy. Ideggyógy. Szle. 59(7-8), 261-267 (2006)

47. Grover S, Chakrabarti S, Hazari N, Avasthi A. Effectiveness of electroconvulsive therapy in patients with treatment resistant schizophrenia: A retrospective study. Psychiatry Res. 2017 Mar;249:349-353

48. Lally J, Tully J, Robertson D, Stubbs B, Gaughran F, MacCabe JH. Augmentation of clozapine with electroconvulsive therapy in treatment resistant schizophrenia: A systematic review and meta-analysis. Schizophr. Res. 171(1-3), 215-224 (2016)

49. Klapheke MM. Combining ECT and antipsychotic agents: benefits and risks. ConvulsTher 1993;9(4):241-255

50. Varma S, Bishara D, Besag FMC, Taylor D. Clozapine-related EEG changes and seizures: dose and plasma-level relationships. Ther. Adv. Psychopharmacol. 1(2), 47-66 (2011)

51. Whittaker R, Scott A, Gardner M. The prevalence of prolonged cerebral seizures at the first treatment in a course of electroconvulsive therapy. J. ECT. 23(1), 11-13 (2007).

52. Merrill DB, Dec GW, Goff DC. Adverse cardiac effects associated with clozapine. J. Clin. Psychopharmacol. 25(1), 32-41 (2005).

53. Masiar SJ, Johns CA. ECT following clozapine. Br J Psychiatry 1991;158:135-136.

54. Safferman AZ, Munne R. Combining clozapine with ECT. ConvulsTher 1992;8:141-143

55. Park S, Lee M. Successful electroconvulsive therapy and improvement of negative symptoms in refractory schizophrenia with clozapine-induced seizures: a case report. Psychiatr. Danub. 26(4), 360-362 (2014)

56. Grubisha M, Gopalan P, Azzam PN. Takotsubo cardiomyopathy in a young man after maintenance electroconvulsive therapy and clozapine initiation: a case report. J ECT 2014;30:e40-41

57. Semkovska M, McLoughlin DM. Objective cognitive performance associated with electroconvulsive therapy for depression: a systematic review and meta-analysis. Biol. Psychiatry. 68(6), 568-577 (2010)

58. Lefaucheur J-P, André-Obadia N, AntalA,Ayache SS, Baeken C, Benninger DH, Cantello RM et al. Evidence-based guidelines on the therapeutic use of repetitive transcranial magnetic stimulation (rTMS). Clin. Neurophysiol. Off. J. Int. Fed. Clin. Neurophysiol. 125(11), 2150-2206(2014)

59. Zyss T, Rachel W, Datka W, Dudek D, Zięba A, Gorczyca P et al. Przezczaszkowa stymulacja magnetyczna w terapii psychiatrycznej . Prz. Lek. 72(7); 2015: 371-375

60. Mäkelä J: A brief history of magnetic stimulation. BioMag Laboratory, HUSLAB, Helsinki University Central Hospital. Helsinki 2008

61. Langguth B, Eichhammer P, Zowe M, Marienhagen J, Spiessl H, Hajak G. Neuronavigated transcranial magnetic stimulation and auditory hallucinations in a schizophrenic patient: Monitoring of neurobiological effects. Schizophr. Res. 84(1), 185-186 (2006)

62. Otani VH, Shiozawa P, Cordeiro Q, Uchida RR. A systematic review and meta-analysis of the use of repetitive transcranial magnetic stimulation for auditory hallucinations treatment in refractory schizophrenic patients. Int J Psychiatry ClinPract. 2015;19(4):228-32

63. Shi C, Yu X, Cheung EF, Shum DH, Chan RC. Revisiting the therapeutic effect of rTMS on negative symptoms in schizophrenia: a metaanalysis. Psychiatry Res 2014; 215:505-513

64. Rosa MO, Gattaz WF, Rosa MA, Rumi DO, Tavares H, Myczkowski $M$ et al. Effects of repetitive transcranial magnetic stimulation on auditory hallucinations refractory to clozapine. J. Clin. Psychiatry. 68(10), 1528-1532 (2007)
65. de Jesus DR, Gil A, Barbosa L, Lobato MI, Magalhães PV, Favalli GP et al. A pilot double-blind sham-controlled trial of repetitive transcranial magnetic stimulation for patients with refractory schizophrenia treated with clozapine. Psychiatry Res. 188(2), 203-207 (2011)

66. d'Alfonso AAL, Aleman A, Kessels RPC, Schouten EA, Postma A,van Der Linden JA et al. Transcranial magnetic stimulation of left auditory cortex in patients with schizophrenia: effects on hallucinations and neurocognition. J Neuropsychiatry ClinNeurosci. 2002;14(1):77-79

67. Eberle M-C, Wildgruber D, Wasserka B, Fallgatter AJ, Plewnia C. Relief From Chronic Intractable Auditory Hallucinations After Long-Term Bilateral Theta Burst Stimulation. Am. J. Psychiatry. 167(11), 1410-1410 (2010)

68. Koops S, Dellen E van, Schutte MJL, Nieuwdorp W, Neggers SFW, Sommer IEC. Theta Burst Transcranial Magnetic Stimulation for Auditory Verbal Hallucinations: Negative Findings From a DoubleBlind-Randomized Trial.Schizophr. Bull.42(1), 250-257 (2016)

69. Kim E-J, Yeo S, Hwang I, Park JI, Cui Y, Jin HM et al. Bilateral Repetitive Transcranial Magnetic Stimulation for Auditory Hallucinations in Patients with Schizophrenia: A Randomized Controlled, Cross-over Study. Clin. Psychopharmacol. Neurosci. Off. Sci. J. Korean Coll. Neuropsychopharmacol. 12(3), 222-228 (2014)

70. Blumberger DM, Christensen BK, Zipursky RB, Moller B, Chen R, Fitzgerald $\mathrm{PB}$ et al. MRI-targeted repetitive transcranial magnetic stimulation of Heschl's gyrus for refractory auditory hallucinations. Brain Stimulat. 5(4), 577-585 (2012)

71. Thirthalli J, Bharadwaj B, Kulkarni S, Gangadhar BN, Kharawala S, Andrade C. Successful use of maintenance rTMS for 8 months in a patient with antipsychotic-refractory auditory hallucinations. Schizophr Res 2008; 100:351-352

72. Barr MS, Farzan F, Tran LC, Fitzgerald PB, Daskalakis ZJ. A randomized controlled trial of sequentially bilateral prefrontal cortex repetitive transcranial magnetic stimulation in the treatment of negative symptoms in schizophrenia. Brain Stimulat. 5(3), 337-346 (2012)

73. Fitzgerald PB, Herring S, Hoy K, McQueen S, Segrave R, Kulkarni J et al. A study of the effectiveness of bilateral transcranial magnetic stimulation in the treatment of the negative symptoms of schizophrenia. Brain Stimulat. 1(1), 27-32 (2008)

74. Schneider AL, Schneider TL, Stark H. Repetitive transcranial magnetic stimulation (rTMS) as an augmentation treatment for the negative symptoms of schizophrenia: a 4-week randomized placebo controlled study. Brain Stimulat. 1(2), 106-111 (2008)

75. Rossi S, Hallett M, Rossini PM, Pascual-Leone A, Safety of TMS Consensus Group. Safety, ethical considerations, and application guidelines for the use of transcranial magnetic stimulation in clinical practice and research. Clin. Neurophysiol. Off. J. Int. Fed. Clin. Neurophysiol. 120(12), 2008-2039 (2009)

76. Zyss T. Przezczaszkowa stymulacja stałoprądowa. W: Zyss T, Zięba A, Dudek D, red. Najnowsze techniki neuromodulacyjne $\mathrm{w}$ terapii zaburzeń depresyjnych. Biblioteka Psychiatrii Polskiej. Kraków: Komitet Redakcyjno-Wydawniczy PTP; 2009, s. 161-181

77. Koops S, Dellen E van, Schutte MJL, Nieuwdorp W, Neggers SFW, Sommer IEC. Theta Burst Transcranial Magnetic Stimulation for Auditory Verbal Hallucinations: Negative Findings From a DoubleBlind-Randomized Trial.Schizophr. Bull.42(1), 250-257 (2016).

78. Nitsche MA, Niehaus L, Hoffmann KT, Hengst S, Liebetanz D, Paulus W et al. MRI study of human brain exposed to weak direct current stimulation of the frontal cortex. Clin. Neurophysiol. 2004; 115 (10): 2419-2423

79. Nitsche MA, Doemkes S, Karaköse T, Antal A, Liebetanz D, Lang N et al. Shaping the effects of transcranial direct current 
stimulation of the human motor cortex. J Neurophysiol. 2007;97(4):3109-17

80. Boggio PS, Rigonatti SP, Ribeiro RB, Myczkowski ML, Nitsche MA, Pascual-Leone A e al. A randomized, double-blind clinical trial on the efficacy of cortical direct current stimulation for the treatment of major depression. Int. J. Neuropsychopharmacol. 2008; 11 (2): 249-254. 71

81. Fregni F, Boggio PS, Nitsche MA, Marcolin MA, Rigonatti SP, Pascual-Leone A. Treatment of major depression with transcranial direct current stimulation. Bipolar Disord. 2006; 8 (2): 203-204.72

82. Nitsche MA, Boggio PS, Fregni F, Pascual-Leone A. Treatment of depression with transcranial direct current stimulation (tDCS): a review. Exp. Neurol. 2009; 219 (1): 14-19.73

83. Zyss T. Przezczaszkowa stymulacja stałoprądowa tDCS i inne pokrewne techniki $w$ terapii zaburzeń psychicznych. Psychiatr. Pol. 2010: 44 (4) s.505-518

84. Caetano SC, Fonseca M, Olvera RL, Nicoletti M, Hatch JP, Stanley JA et al. Proton spectroscopy study of the left dorsolateral prefrontal cortex in pediatric depressed patients. Neurosc. Lett. 2005; 384 (3): 321-326

85. Andrade C. Transcranial direct current stimulation for refractory auditory hallucinations in schizophrenia. J. Clin. Psychiatry. 74(11), e1054-1058 (2013)

86. Brunelin J, Mondino M, Gassab L, Haesebaert F, Gaha L, SuaudChagny MF et al. Examining Transcranial DirectCurrent Stimulation (tDCS) as a Treatment for Hallucinations in Schizophrenia. Am. J. Psychiatry. 169(7), 719-724 (2012)

87. Fröhlich F, Burrello TN, Mellin JM, Cordle AL, Lustenberger CM, Gilmore JH et al.. Exploratory study of once-daily transcranial direct current stimulation (tDCS) as a treatment for auditory hallucinations in schizophrenia. Eur. Psychiatry J. Assoc. Eur. Psychiatr. 33, 54-60 (2016)

88. Jacks S, Kalivas B, Mittendorf A, Kindt C, Short EB. Transcranial Direct-Current Stimulation as an Adjunct to Electroconvulsive Therapy and Clozapine for Refractory Psychosis. Prim. Care Companion CNS Disord. [Internet]. 16(3) (2014). Available from: http://www.ncbi.nlm.nih.gov/pmc/articles/PMC4195645

89. Cretaz E, Brunoni AR, Lafer B. Magnetic Seizure Therapy for Unipolar and Bipolar Depression: A Systematic Review. Neural Plast. Neural Plast. 2015, 2015, e521398 (2015)

90. Magnetic Seizure Therapy (MST) for Treatment Resistant Depression, Schizophrenia and Obsessive Compulsive Disorder. https://clinicaltrials.gov/ct2/show/NCT01596608

\section{Correspondence address}

Joanna Gałaszkiewicz

I KlinikaPsychiatrii, Psychoterapii i WczesnejInterwencji

Ul. Głuska 1, 20-439 Lublin

e-mail: a.galaszkiewicz@interia.pl

Otrzymano: 02.11.2016

Zrecenzowano: 05.12.2016

Przyjęto do druku: 06.12.2017 